\title{
STUDIES ON LANDSLIDES OF AGRICULTURAL LAND IN KŌBE GROUP, TERTIARY DEPOSIT
}

\author{
Part 5. On the Stability Analysis of Landslide-Slope in the Agricultural Land at K- \\ Section, Kōbe City
}

Yöhaku ISHIDA*, Eiji OZAKI* and Isamu SAKANE*

\section{SYNOPSIS}

About the sliding slope of agricultural land at K-section in Kita ward, Kobe City, where C.I. P. concrete piles were constructed as slide check works, we computed the safety factors before and after the construction of piles and obtained the following results.

1) The safety factor of slope decreased with the decrement in values of soil angle of internal friction $\phi$ and cohesion $C$.

2) The safety factor computed by the expedient method of the pile-unconstructed slope as control showed that the slope wasn't in a state of stability.

3) There was a small difference between a safety factor modified by Bishop's method and that by the expedient one. Therfore, the safety factors by Bishop's also showed that the slope wasn't in a state of stability.

4) The safety factor of the pile-unconstructed slope processed on the computer was less than $F_{s}=$ 1.2. And it showed that the slope wasn't in a state of stability.

5) In the case of $\mathrm{K}$-section where the groundwater level was deep and the slide plane was shallow, the safety factor of the pile-unconstructed slope showed the considerably large value.

6) The safety factor of slope was increased after the construction of piles, showing that the slope became stable.

7) Examing on an economy of the slide check works in case that the safety factor of the pileunconstructed slope is considerably large, the following may be comprehended; i. e., even if the interval of piles is expanded to a certain extent, the slope is in a state of stability.

8) Similarly even if the number of pile-lines is decreased to a certain extent, the slope is in a state of stability.

\section{INTRODUCTION}

The material composing any slope has a natural tendency to slide under the influence of garvitational and other forces (such as those due to tectonic stresses, seismic activity, etc.) which is resisted by the shearing resistance of the material ${ }^{8)}$. Instability occures when the shearing resistance is not enough to counterbalance the forces tending to cause movement along any surface within a slope ${ }^{8)}$.

As the causes to make slopes instability, the following factors are thought to reduce the shearing resistance of the soil materials ${ }^{5)}$. i.e.; (a) swelling in clayey soil, (b) pore water pressure, (c) insufficient compaction of soil, (d) minute cracks, (e) strain in soil, (f) melting of frost soil or

\footnotetext{
* Faculty of Agriculcure, Kobe University
} 
ice lens, (g) weakened fixer, (h) oscillation of granular soil and so on ${ }^{5}$.

The problems of slope stability are analysed by the repeated calculations when the profile of the slope, the slide plane, the groundwater level, existance of slide check works, mechanical constants of them and the intensity constants of soil are known. But these calculations have been felt troublesome, which, therfore, judging an effect of a slide check work has been difficult.

This paper deals with an analysis on the particular slope in order to show an effect of the slide check work using piles.

\section{ANALYSIS OF SLOPES AND METHOD}

We chose the C.I.P. pile-constructed slope at K-section in Kita Ward, Kobe City described in the previous paper as the objective slope ${ }^{3)}$. The $\mathrm{D}$-D-section is our analyzed slope. (see Figure 1-2 in the previous paper) Considering the boring cores sampled and such like, we estimated the slide plane as shown in Figure 2 by dotted lines ${ }^{3)}$.

The safety factor about the estimated slide plane was calculated by the dismemberment method ${ }^{1}$. According to the sitiuations in situ, D-D-section was separated into 26 slices and Table 1 shows the values of slices.

A safety factor is calculated at first by knowing the critical slide plane that gives maximum sliding force $\left(F_{\max }\right)$ or moment $\left(M_{\max }\right)$, and then calculating the ratio between the resisting force $\left(F_{r}\right)$ or moment $\left(M_{r}\right)$ anti-sliding and the $F_{\max }$ or $M_{\max }$ along that plane. Namely, a safety factor is formulated as follows:

a) Slide "plane" surface

$$
F_{s}=F_{r} / F_{\max }
$$

b) Slide "curved" surface

$$
F_{s}=M_{r} / M_{\max }
$$

The standard values of safety factors are shown as follows ${ }^{2)}$ :

$F_{s}<0.90$ : It is certain that the slide occures.

$0.90<F_{s}<0.95:$ It is almost certain so.

$0.95<F_{s}<1.00:$ It is possibly so.

$1.00<F_{s}<1.20:$ It is stable only on the special condition.

1. $20<F_{s}$ : The standard value for the Banking, Earth-dam, etc.

Generally, a safety factor of a slope on the slide is nearly equal to $1^{7)}$. In decreasing it to 0.95 , a slope of clayey soil begins to move rapidly. Therefore, the value from 0.96 to 1.00 is under, discussion safe that a safety factor of pile-unconstructed slope should be below $F_{s}=1.00$.

In this paper, we calculated the safety factor of unconstructed slope using the expedient method at first and then modifying them by Bishop's method. The results of the long-dated continuous measurement and the lateral forces acting on piles by the proposed equations in the previous paper were used for calculating safety factors of slopes having the slide check piles ${ }^{336)}$.

Every calculation was processed by our own BASIC programs on the system of NEC's personal computer (PC-8801), mini-floopy disk unit (PC-8031-2W) and high-speed-serial dot-impact printer (PC-8023-C).

\section{Results and Discussion}

\section{1) Trials by an Expedient Method}

Considering an ultimate equilibration, we define the safety factor to landslide by the ratio between the actual shearing resistance of the soil and the shearing resistance required to keep the 
Table. 1. Numerical values of slices (D-D-section, K-district)

\begin{tabular}{c|r|r|r|r|r}
\hline section & \multicolumn{1}{|c|}{$b$} & \multicolumn{1}{c|}{$l$} & \multicolumn{1}{c|}{$\alpha$} & \multicolumn{1}{c}{$\mathrm{A}$} & \multicolumn{1}{c}{$\AA$} \\
\hline 1 & 2.3 & 4.6 & 56.0 & 4.36 & 0.00 \\
2 & 1.5 & 1.9 & 35.0 & 5.18 & 0.00 \\
3 & 4.2 & 4.4 & 16.0 & 18.06 & 0.00 \\
4 & 1.2 & 1.2 & 10.0 & 5.70 & 0.00 \\
5 & 16.1 & 16.2 & 5.0 & 82.11 & 0.00 \\
6 & 1.5 & 1.5 & 5.0 & 8.18 & 0.00 \\
7 & 9.5 & 9.5 & 5.0 & 53.26 & 0.00 \\
8 & 0.8 & 0.8 & 5.0 & 4.40 & 0.00 \\
9 & 9.6 & 9.6 & 5.0 & 51.36 & 0.00 \\
10 & 2.0 & 2.0 & 5.0 & 10.40 & 0.00 \\
11 & 5.8 & 5.8 & 5.0 & 28.71 & 0.00 \\
12 & 0.9 & 0.9 & 5.0 & 4.37 & 0.00 \\
13 & 8.9 & 8.9 & 5.0 & 42.96 & 0.00 \\
14 & 1.0 & 1.0 & 5.0 & 4.65 & 0.10 \\
15 & 15.0 & 15.1 & 5.0 & 60.75 & 14.25 \\
16 & 1.2 & 1.2 & 5.0 & 3.84 & 2.34 \\
17 & 6.8 & 6.8 & 5.0 & 18.02 & 15.98 \\
18 & 4.8 & 4.8 & 5.0 & 9.60 & 13.68 \\
19 & 2.5 & 2.5 & 5.0 & 4.12 & 7.13 \\
20 & 0.5 & 0.5 & 5.0 & 0.70 & 1.35 \\
21 & 4.3 & 4.3 & 5.0 & 4.69 & 10.97 \\
22 & 1.8 & 1.8 & -8.0 & 1.53 & 3.87 \\
23 & 4.3 & 4.3 & -8.0 & 3.01 & 5.59 \\
24 & 0.6 & 0.6 & -8.0 & 0.39 & 0.36 \\
25 & 0.9 & 0.9 & -8.0 & 0.27 & 0.36 \\
26 & 0.3 & 0.3 & -8.0 & 0.05 & 0.05 \\
\hline. & & & &
\end{tabular}

$b:$ width of slice $(\mathrm{m})$

$l:$ length of slide line $(\mathrm{m})$

$\alpha$ : angle of slide line $(\mathrm{deg})$

A : area over G. W.L. (m)

$\AA$ : area under G. W. L. (m) equilibrium condition.; i. e.,

$$
S=\frac{1}{F_{s}}\left\{C^{\prime}+(\sigma-u) \tan \phi^{\prime}\right\}
$$

Where

$S:$ The actual shearing resistance of the soil (Figure 1)

$F_{s}:$ Safety factor of slope

$C^{\prime}$ : Cohesion

$\sigma:$ Normal stress

$u$ : Pore water pressure

$\phi^{\prime}$ : Angle of internal friction

This complies with Fellenius method and $F_{s}$ is led uniformly. This mrthod is called as "Bishop's ultimate design method". And it is applied to the slopes of earth fill dams and long dated stability analysis for the cuttings and natural slopes ${ }^{1 / 4)}$.

In Figure 1, separating the slide plane of the circular arc shape (the center $O$. radius $r$ ) into several slices, we consider a balance of powers acting on each slice.

Normal stress is equal to $P / l$ and the exhibited shearing stress to satisfy the ultimate equilibration is:

$$
S=\frac{1}{F_{s}}\left\{C^{\prime}+\left(\frac{P}{l}-u\right) \tan \phi^{\prime}\right\}
$$

The shearing forces acting on the base of the slice is equal to Sl. The moment of the weight of the soil body $\mathrm{ABCD}$ about $\mathrm{O}$ is equal to the moment of the external forces applied on the slide plane. (the internal forces $X, E$ aren't needed): i. e., knowing

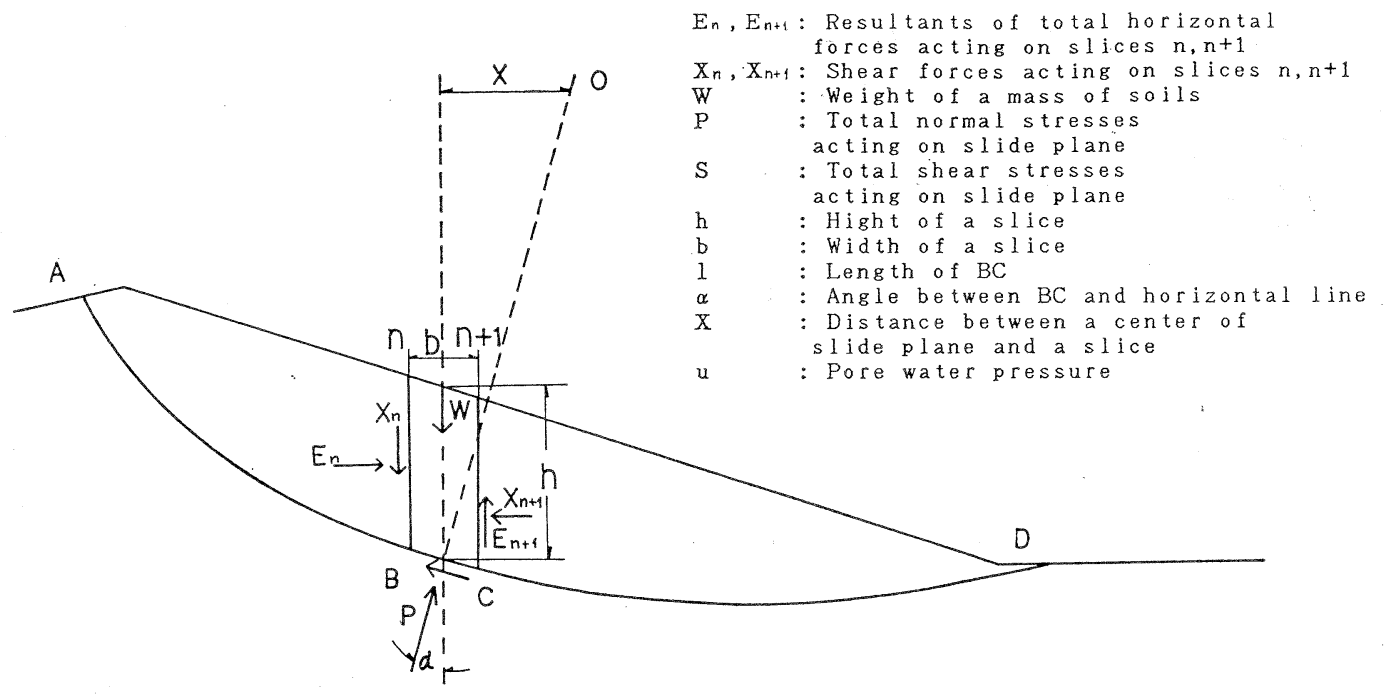

Fig. 1 Each element of a slice 


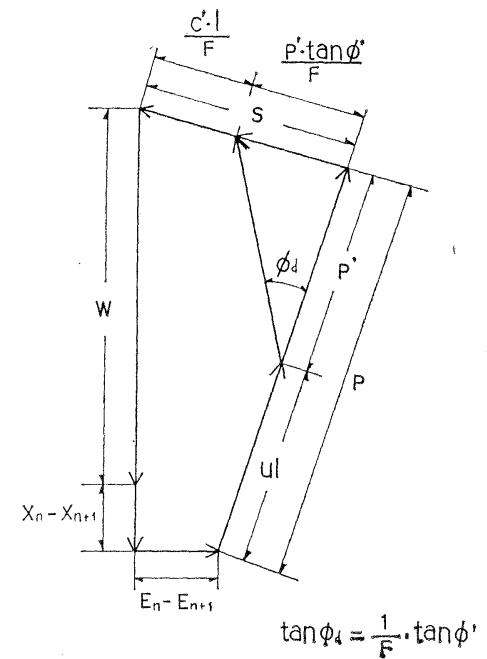

Fig. 2 Bishop's modifying component

$$
\sum W_{x}=\Sigma S r=\Sigma S l r
$$

and Eq. (3), we get

$$
F_{s}=\frac{r}{\sum W_{x}} \sum\left\{C^{\prime} l+(P-u l) \tan \phi^{\prime}\right\}
$$

Observing the figure, we find the vertical component $P$ of the force acting on $\mathrm{BC}$,

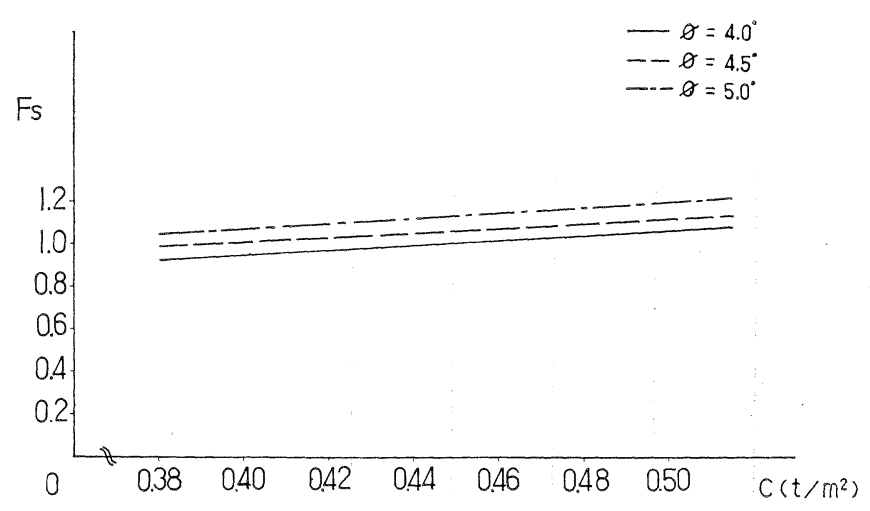

Fig. 3 Safety factor of the slope by an expedient

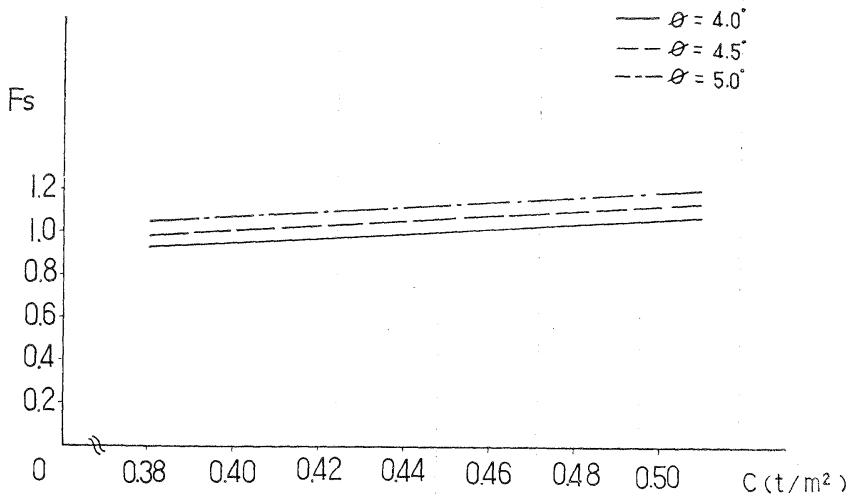

Fig. 4 Safety factor of the slope by Bishop's method

$$
P=\left(W+X_{n}-X_{n+1}\right) \cos \alpha-\left(E_{n}-E_{n=1}\right) \sin \alpha
$$

where

$\alpha$ : Angle of slide plane to the horizon

Carrying this equation into Eq. (5), we have

$$
\begin{aligned}
F_{s}= & \frac{r}{\Sigma \mathrm{W}_{x}} \Sigma\left\{C^{\prime} l-\tan \phi^{\prime}\left(W^{\prime} \cos \alpha-u l\right)\right. \\
& \left.\left.-\tan \phi^{-}\left(X_{n}-X_{n+1}\right) \cos \alpha-\left(E_{n}-E_{n+1}\right) \sin \alpha\right\}\right]
\end{aligned}
$$

No external force is acting on the slope and so internal forces keep a balance on the whole. Therefore, we write,

$$
\sum\left(X_{n}-X_{n+1}\right)=0, \quad \Sigma\left(E_{n}-E_{n+1}\right)=0
$$

But as long as $\phi^{\prime}$ and $\alpha$ aren't fixed, the terms involving $X_{n}$ and $E_{n}$ don't fade away from Eq. (6). Neglecting the following term of Eq. (6):

$$
\sum \tan \phi^{\prime}\left\{\left(X_{n}-X_{n+1}\right) \cos \alpha-\left(E_{n}-E_{n+1}\right) \sin \alpha\right\}
$$

and substituting $X=r \sin \alpha$ for Eq. (6), we have ${ }^{4)}$

$$
F_{s}=\frac{1}{\sum W \sin \alpha} \sum\left\{C^{\prime} l+\tan \phi^{\prime}(W \cos \alpha-u l)\right\}
$$

Using this equation, we have the results as shown in Figure 3.

According to the decrement of soil's cohesion $C$ and angle of internal friction $\phi$, the safety factor decreases.

The safety factor of the slope with no pile at $\mathrm{K}$-section by this trial was below $F_{s}=1.2$ and showed that the slope wasn't stable. 


\section{2) Modification by Bishop's Method}

Generally, the equations by an expedient method are apt to give rather high values, so we examined the adjustment by Bishop's method ${ }^{4)}$.

Observing Figure 2, we have

$\tan \phi=\tan \phi^{\prime} / F_{s}$

and considering the balance of the vertical components,

$W+\left(X_{n}-X_{n+1}\right)=\left(P^{\prime}+u l\right) \cos \alpha+S_{x} \sin \alpha$

$S=\left(C^{\prime} l+P^{\prime} \tan \phi^{\prime}\right) / F_{s}$

on the condition of $P^{\prime}=P-u l$

Eliminating " $S$ " from the both sides of this equation, we have the following equation about " $P$ ",

$$
P^{\prime}=\frac{W+X_{n}-X_{n+1}-1\left\{u \cos \alpha+\left(C^{\prime} / F\right) \sin \alpha\right\}}{\cos \alpha-\left(\tan \phi^{\prime} \cdot \sin \alpha\right) / F_{s}}
$$

Then carrying this into Eq. (5), and defining

$$
l=b \cos \alpha, \quad X=r \sin \alpha, \quad u=\bar{B}(W / b),
$$

we have

$$
\begin{aligned}
F_{s}= & \frac{1}{\sum W \sin \alpha} \sum\left[\left\{C^{\prime} b+\tan \phi^{\prime} \cdot W(1-\widetilde{B})+\left(X_{n}-X_{n+1}\right) .\right.\right. \\
& \frac{\sec \alpha}{1-\left(\tan \phi^{\prime} \cdot \tan \alpha\right) / F_{s}} \cdots \ldots \ldots \ldots \ldots \ldots \ldots \ldots \ldots \ldots \ldots \ldots \ldots \ldots \ldots \ldots \ldots \ldots \ldots \ldots \ldots \ldots \ldots \ldots \ldots
\end{aligned}
$$

From this we are able to calculate $F_{s}$.

We must calculate the term of $\left(X_{n}-X_{n+1}\right)$ in Eq. (8) by the successive approximate method and satisfy the condition about the internal force terms, ; i.e.,

$\Sigma\left(X_{n}-X_{n+1}\right)=0, \quad \Sigma\left(E_{n}-E_{n+1}\right)=0$

In addition we must satisfy the rationality about lateral forces'lines of action between the slices and that no slice has unbalance moments.

The condition of $\Sigma\left(X_{n}-X_{n+1}\right)=0$ can be satisfied by the appropriate $X_{n}$ and the corresponding $\Sigma\left(E_{n}-E_{n+1}\right)=0$ can be calculated by using Eq. (8).

Solving the force on the tangent, we have

$$
\left(W+X_{n}-X_{n+1}\right) \sin \alpha+\left(E_{n}-E_{n+1}\right) \cos \alpha=S
$$

or

$$
\left(E_{n}-E_{n+1}\right)=S \cdot \sec \alpha-\left(W+X_{n}-X_{n+1}\right) \tan \alpha
$$

assuming in Eq. (8)

$$
F_{s}=\frac{1}{\sum W \sin \alpha} \sum(m)
$$

we have $S=m / F_{s}$ and $S$ shows the shearing force acting along the base plane of slide. Considering

$\sum\left(E_{n}-E_{n+1}\right)=\Sigma\left[\left(m / F_{s}\right) \sec \alpha-\left(W+X_{n}-X_{n+1}\right) \tan \alpha\right]=0$,

we find that $X$ must satisfy the following condition:

$\Sigma\left[\left(m / F_{s}\right) \sec \alpha-\left(W+X_{n}-X_{n+1}\right) \tan \alpha\right]=0$.

Many distributions of $X_{n}-X_{n+1}$ satisfy this equation but the change of $F_{s}$ corresponding to these isn't very important and the change is below $1 \%$ at the standard section. In the practical application substituting $X_{n}-X_{n+1}=0$ for Eq. (8), we have

$$
F_{s}=\frac{1}{\sum W \sin \alpha} \Sigma\left[\left\{C^{\prime} b+W(1+\bar{B}) \tan \phi^{\prime} \cdot \frac{\sec \alpha}{1+\left(\tan \alpha \cdot \tan \phi^{\prime}\right) / F_{s}}\right\}\right]
$$

and we use this equation on our calculations. " $F_{s}$ " is in the each side of Eq. (9). So, at first calculating $F_{s}$ by Eq. (7), then carrying this value of $F_{s}$ into the right side of Eq. (9) and calculating this, we have the "first" value of $F_{s}$ in the left side. Next this "first" value of $F_{s}$ is also 
carried into Eq. (9) and this operation is repeated until the difference comes nearly to zero. The results are shown in Figure 4.

The safety factor modified by Bishop's method was a little smaller than one by the expedient method but there was a small difference. We considered this was owing to shallow depth of landslide phenomenon.

Therefore, the safety factor by Bishop's method showed that the slope wasn't in a state of stability.

\section{3) The Method by Computer (considering without pore water pressure)}

a) Safety factor of slope with no pile

Slope moving is often owing to the combination of the gravity action and some other effects. So in this paper we examined to analyse the stability of slope, attaching importance to the effect of gravityshearing stress. This analysis to consider the balance of forces is one of the most basic methods.

In this section we use the shearing resistance of soil.; i.e.,

$$
\tau=C+\sigma \tan \phi
$$

And we use the cohesion $C$ and angle of internal friction $\phi$ on total stresses founded upon the undrained shear test. (The results of tests will be published in another paper.) Owing to circumstances of the pile effect analysis, this method is different from ones of the previous section in point of pore water pressure. (This method dosen't consider any pore water pressure. )

Therefore, we have the equation from Eq. (1)

$$
F_{s}=\frac{\sum_{i=1}^{n}\left(C l_{i}+W_{i} \cdot \cos \theta_{i} \cdot \tan \phi\right)}{\sum_{i=1}^{n} W_{i} \cdot \sin \theta_{i}}
$$

where

$\theta$ : Angle of slide plane to the horizon $\bar{W}_{i}$ : Weight of slice

Noting the area over groundwater level $A_{t i}$ and that below it $A_{\text {sati }}$ we write $W_{i}$ of Eq. (10):

$$
\bar{W}_{i}=\gamma_{t} A_{t i}+\gamma_{\text {sat }} A_{\text {sati }}
$$

where

$$
\gamma_{t}: \text { Wet unit weight }
$$

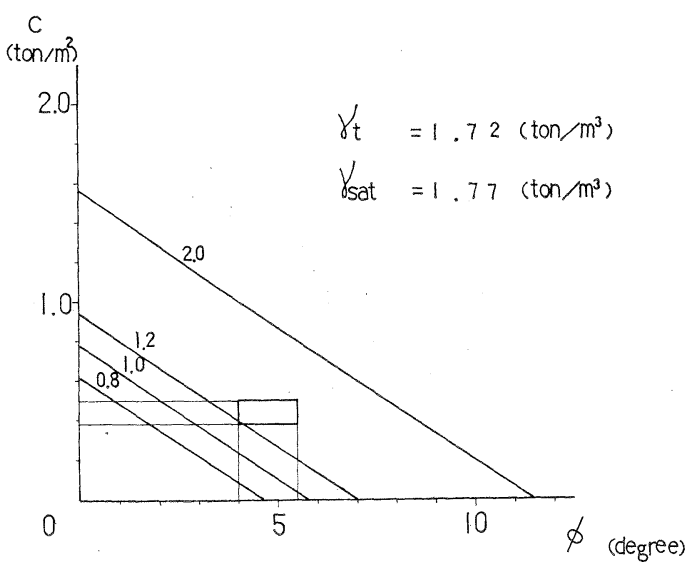

Fig. 5 Safety factor of the slope before constructing

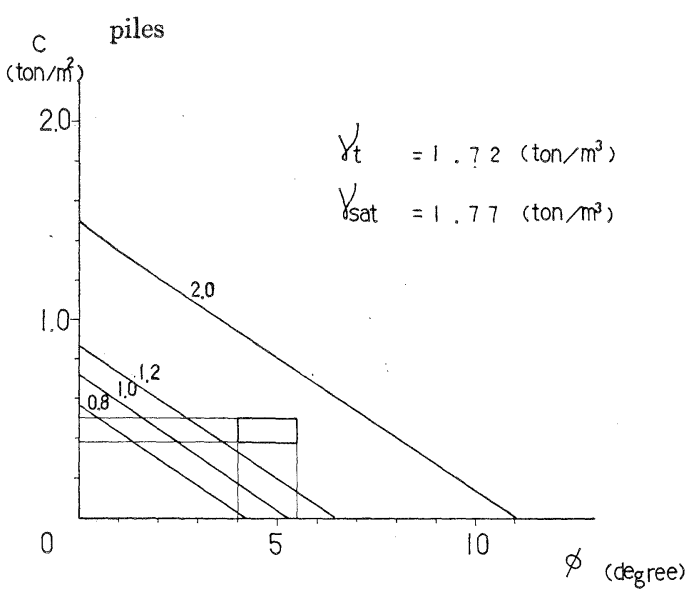

Fig. 6 Safety factor of the slope after constructing piles

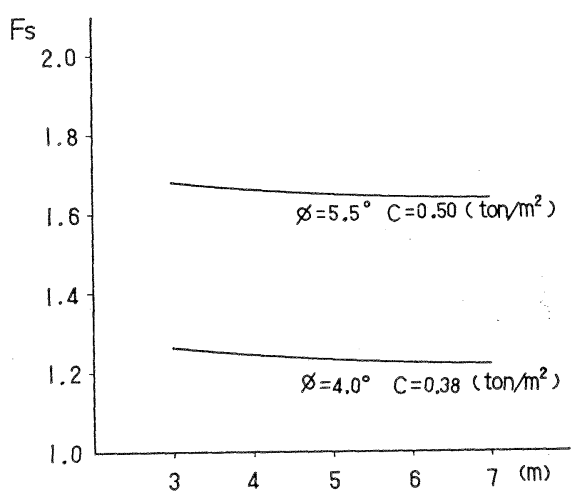

Fig. 7 Interval of piles and safety factor of slope.

Table. 2 Number of pile-lines and safety factor of slope

\begin{tabular}{lr|c|c|c|c}
\hline \hline$\phi, C$ & pile-lenes & 3 & 2 & 1 & 0 \\
\hline$\phi: 4.0^{\circ}, C: 0.38$ ton $/ \mathrm{m}^{2}$ & 1.2604 & 1.2364 & 1.2109 & 1.1859 \\
$\phi: 5.5^{\circ}, C: 0.50$ ton $/ \mathrm{m}^{2}$ & 1.6809 & 1.6555 & 1.6286 & 1.6031 \\
\hline
\end{tabular}


$\gamma_{\text {sat }}:$ Saturated unit weight

Therefore, we have the next equation from Eq. (10) and (11),

$$
F_{s}=\frac{\sum_{i=1}^{n}\left\{C l_{i}+\left(\gamma_{t} A_{t i}+\gamma_{s a t} A_{s a t i}\right) \cos \theta \cdot \tan \phi\right\}}{\sum_{i=1}^{n}\left(\gamma_{t} A_{t i}+\gamma_{s a t} A_{s a t i}\right) \sin \theta_{i}}
$$

Using Eq. (12), and carrying $\gamma_{t}=1.72 \mathrm{ton} / \mathrm{m}^{3}$ and $\gamma_{\text {sat }}=1.77 \mathrm{ton} / \mathrm{m}^{3}$ into the same sections in Sec. (1), (2) of Chap. III, and calculating the safety factors with the additional, expanded ranges of $C$ and $\phi$, we have the results in Figure 5. (The program lists are omitted.) The categoly of $C$ is $0 \sim 2.20 \mathrm{ton} / \mathrm{m}^{2}$ and the calculating step is $0.10 \mathrm{ton} / \mathrm{m}^{2}$. And the categoly of $\phi$ is $0^{\circ} \sim 11^{\circ}$ and the step is $30^{\prime}$. So we calculated the 529 cases in all. In $\phi=4^{\circ}$ and $C=0.38 \mathrm{ton} / \mathrm{m}^{2} F_{s}$ came to 1.186 and this showed that the slope with no pile wasn't in a state of stability.

Using this method, for example, we have,

$$
\begin{aligned}
& \phi=0^{\circ} 30^{\prime}, C=0.70 \operatorname{ton} / \mathrm{m}^{2}: F_{s}=0.9860 \\
& \phi=2^{\circ} 00^{\prime}, C=0.50 \operatorname{ton} / \mathrm{m}^{2}: F_{s}=0.9906 \\
& \phi=3^{\circ} 30^{\prime}, C=0.30 \operatorname{ton} / \mathrm{m}^{2}: F_{s}=0.9957
\end{aligned}
$$

Consequently, we estimated the safety factors of slopes with no pile at $\mathrm{K}$-section as $F_{s} \leqq 1.2$. This value can be grown by constructing slide check works.

b) Safety factors of slopes with slide check piles

There are many kinds of slide check works. As one of these the pile (driving) method is adopted to many agricultural lands because this method gives no trouble to agricultural works. Also in $\mathrm{K}$-section C.I.P. concrete piles were adopted as the slide check works. Therefore, we computed the effect of the slide check piles. Regarding the lateral forces ${ }^{3)}$ acting on the actual piles as resistances to slide, we computed judgments and the results are shown in Figure 6.

In the same condition of $\phi, C$ as Sec. (1), (2) (i. e.; $\phi=4^{\circ}$ and $C=0.38$ ton $/ \mathrm{m}^{2}$ ), $\quad F_{s}$ was 1.222 and its increment by piles was 0.036 . This value shows that the slope comes to be in a state of stability. The possible reasons why the increment of the safety factor of slope by piles is small are that in K-section (1) the G.W.L. is deep, (2) the slide plane is shallow and (3) therefore, the force acting on the actual piles is small, i.e.; the reasons (1) and (2) give the rather large safety factor of slope with no pile.

c) Economical growing the safety factor of slope

When the safety factor of slope with no pile isn't in a state of stability and it is rather large, the slope can be stabilized with small slide check works. In K-section the reasons (1) the G. W. L. is deep, (2) the slide plane is shallow as stated above) gave the rather large value of the safety factor of slope with no pile. And we used somewhat small values of $\phi$ and $C$ in the calculation.

Therfore, it is significant to examine saving slide check works with in the range of $F_{s} \geqq 1.2$.

In this section the relation between the interval of piles and the safety factor is shown in Figure. 7. Expanding the interval of piles doesn't give much influence on the forces acting on piles (about 3\%). Thus, this doesn't give much influence on the stability of piles themselves. In Figure 7 the two calculated examples $\left(\phi=5.5^{\circ}, C=0.5 \mathrm{ton} / \mathrm{m}^{2}\right.$ and $\phi=4.0^{\circ}, C=0.38 \mathrm{ton} / \mathrm{m}^{2}$ are shown. It is said that the slope is safe even in $7 \mathrm{~m}$ interval. But the continuously measured values for four years show that the intermediate pile has small strain. This strain shows existence of a stress acting on the intermediate pile through an interval between a pile and another. Expanding the interval has danger that the force through the interval between a pile and another is increased. So we can estimate that the current interval $(3 \mathrm{~m})$ is suitable in $\mathrm{K}$-section. Next, the relation between the number of lines and safety factor that was calculated in the same condition of $\phi$ and $C$ is sh. 
own in Table 2. In this table the interval of piles is fixed under the present condition. This shows only one line of piles give the required safety factor. Therefore, we choose the safety side, i. e.; two lines of piles. In this case we must place the lines of piles in the deep position of the slide plane.

\section{(ACKNOWLEDGMENTS)}

The authors would like to express their thanks to Hyogo Prefectural Authorities for the co-operation in placing the testing piles.

\section{References}

1) ARPAD, K., : Bodenmechanik, Veb Verlag Für Bauwesen Berlin, 29-41, 1964.

2) FUJIWARA, A. : Analysis and Prevent-Plan of Landslides, Rikoh Pub. Co., Tokyo, 144-151, 1979 (in Japanese).

3) ISHIDA, Y., OZAKI, E. and I. SAKANE: Landslides, Soc.

4) Japanese Society of Soil Mechanics and Foundation Engineering: Handbook of Soil Mechanics and Foundation Engineering, Gihodo Pub. Co., Tokyo, 199-213, 1966 (in Japanese).

5) KAWAKAMI, F. : Soil Mechanics, Morikita Pub. Co., Tokyo, 137, 1981 (in Japanese)

6) OZAKI, E. and Y. ISHIDA: Sci. Rept. Fac. Agr. Kobe Univ., 16, 127-134, 1984.

7) Quido Záruba and Vojetech Mencl: translation MATSUO, S., ; Landslides and their Control, Kajima Institute Pub. Co., Tokyo, 118-120, 1971.

8) R.N. CHOWDHURY.: Slope Analysis, Elsevier Scientific Pub. Co., New York, 3, 1978.

第三紀層神戸層群に和ける農地地ずベりに関する研究

\section{第 5 報 神戸市 K-地区における農地地すべり斜面の安定解析}

\section{石田陽博・尾崎㕡司・坂根 勇}

\section{要 約}

地すべり抑止工として C.I.P.コンクリート杭が施工された。神戸市北区K-地区に掠ける農地地すべり斜面につい $\tau$, 杭施工前後の安全率を解析し, 次の結果を得た。

1) 土塊の粘着力 $C$ 及び内部摩擦角 $\phi$ の減少に伴い斜面安全率は減少する。

2）簡便法による杭施工前斜面安全率の計算值は，斜面が安定状態でないことを示した。

3）Bishop 法による修正值は，簡便法による計算值との差が僅小であった。従ってBishop 法による修正値も斜面 が安定状態でないことを示した。

4）計算機による杭施工前斜面安全率の計算值も 1.2 以下で，斜面が安定状態でないことを示した。

5）地下水位が深く，すべり面が浅いK-地区の場合，杭施工前斜面安全率はかなり大きい值を示した。

6）杭施工後の斜面安全率は増加し，斜面が安定状態になったことを示した。

7）抑止工の経済性を検討した結果，杭施工前斜面安全率がかなり大きい場合，杭間隔をある程度拡大しても斜面 の安全を得られらことが判明した。

8）同様に杭列数を減らしてる，斜面の安全を得られることが判明した。 